American University Washington College of Law

Digital Commons @ American University Washington College of

Law

Contributions to Books

Scholarship \& Research

2014

\title{
Transparency in International Economic Relations and the Role of the WTO
}

Padideh Ala'i

American University Washington College of Law, palai@wcl.american.edu

Matthew D'Orsi

Follow this and additional works at: https://digitalcommons.wcl.american.edu/facsch_bk_contributions

Part of the International Law Commons, International Trade Law Commons, and the Law and

Economics Commons

\section{Recommended Citation}

Ala'i, Padideh and D'Orsi, Matthew, "Transparency in International Economic Relations and the Role of the WTO" (2014). Contributions to Books. 117.

https://digitalcommons.wcl.american.edu/facsch_bk_contributions/117

This Book Chapter is brought to you for free and open access by the Scholarship \& Research at Digital Commons @ American University Washington College of Law. It has been accepted for inclusion in Contributions to Books by an authorized administrator of Digital Commons @ American University Washington College of Law. For more information, please contact kclay@wcl.american.edu. 


\section{Research Handbook on Transparency}

Edited by

Padideh Ala'i

Professor of Law, American University Washington College of Law, USA

Robert G. Vaughn

Professor of Law and A. Allen King Scholar, American University Washington College of Law, USA

\section{Edward Elgar}

Cheltenham, UK • Northampton, MA, USA 
(C) The Editors and Contributors Severally 2014

All rights reserved. No part of this publication may be reproduced, stored in a retrieval system or transmitted in any form or by any means, electronic, mechanical or photocopying, recording, or otherwise without the prior permission of the publisher.

Published by

Edward Elgar Publishing Limited

The Lypiatts

15 Lansdown Road

Cheltenham

Glos GL50 2JA

UK

Edward Elgar Publishing, Inc.

William Pratt House

9 Dewey Court

Northampton

Massachusetts 01060

USA

A catalogue record for this book is available from the British Library

Library of Congress Control Number: 2014937776

This book is available electronically in the ElgarOnline.com Law Subject Collection, E-ISBN 9781781007945

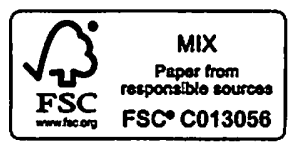

ISBN 9781781007938 (cased)

Typeset by Servis Filmsetting Ltd, Stockport, Cheshire

Printed and bound in Great Britain by T.J. International Ltd, Padstow 


\section{Contents}

Introduction

Robert G. Vaughn and Padideh Ala'i

I. FRAMEWORKS FOR TRANSPARENCY

1. Transparency and closure H. Patrick Glenn

2. The relationship between transparency, whistleblowing, and public trust

A. J. Brown, Wim Vandekerckhove and Suelette Dreyfus

3. Exploring the legal architecture of transparency Elizabeth Fisher

4. The associations of judicial transparency with administrative transparency Robert G. Vaughn

II. CULTURAL AND NATIONAL PERSPECTIVES ON TRANSPARENCY

5. Opposing legal transparency in dynastic China: the persuasive logic of Confucianist views on legal opaqueness John W. Head

6. Transparency and the Shi'i clerical elite Haider Ala Hamoudi

7. Transparency under dispute: public relations, bureaucracy, and democracy in Mexico Irma Eréndira Sandoval

8. When transparency meets politics: the case of Mexico's electoral ballots John Mill Ackerman 
vi Research handbook on transparency

9. The role of the courts in China's progress towards transparency

Liu Wenjing

III. LEGAL APPROACHES TO TRANSPARENCY

10. The history of government transparency Daniel J. Metcalfe

11. The long and winding road to transparency in the UK Shonali Routray

12. Transparency in policymaking - the (mostly) laudable example of the U.S. rulemaking system Jeffrey $S$. Lubbers

13. Faux transparency: ethics, privacy and the demise of the STOCK Act's massive online disclosure of employees' finances

Kathleen Clark and Cheryl Embree

IV. GLOBAL GOVERNANCE AND TRANSPARENCY

14. Transparency at the World Bank Daniel J. Metcalfe

15. The emerging norm of transparency in international environmental governance

David B. Hunter

16. Transparency in international economic relations and the role of the WTO

Padideh Ala'i and Matthew D'Orsi

Concluding reflections

Index 


\section{Transparency in international economic relations and the role of the WTO Padideh Ala'i and Matthew D'Orsi}

\section{INTRODUCTION}

The establishment of the World Trade Organization (WTO)' in 1995 has transformed the consensus-based system of the General Agreement on Tariffs and Trade (GATT 1947) ${ }^{2}$ into a rule-based system, encompassing not only trade in goods (GATT 1994), ${ }^{3}$ but also trade in services (GATS) ${ }^{4}$ and trade-related aspects of intellectual property rights (TRIPS). ${ }^{5}$ As a result of this transformation, transparency of trade-related measures has become a central objective of the multilateral trading system, and trade disputes have focused increasingly on the transparency obligations of Member States under the WTO covered agreements. ${ }^{6}$

Transparency has become central to the mandate of the WTO as a result of the shift in focus of trade negotiations from the reduction of tariffs in the immediate post-World-War-II period to the reduction of non-tariff barriers (NTBs) starting in the 1960s, and finally, to the current focus on regulatory convergence and harmonization. Historically, trade disputes required that a respondent remove any legislative or executive measure in the form of a tariff, quota, or non-tariff barrier that constituted an impediment to cross-border transactions. Today, the WTO recognizes that many governmental measures, including judicial and administrative measures in a number of related spheres, may also constitute legitimate non-tariff barriers, as they are also integral to the workings of a regulatory state. Disputes now focus not only on the content of the measures, but also the extent to which the measures are administered or applied in a transparent or even-handed manner.?

The scope of the transparency provisions contained in the WTO covered agreements, like that of any other provision in the agreements, is dependent upon the mandate of the WTO. Is the WTO's mandate focused solely on trade liberalization? Or is it also focused on the promotion of sustainable development, rule of law, and good governance? As no consensus exists concerning the true nature of its mandate, the WTO is currently in the midst of an identity crisis. ${ }^{8}$ If the WTO is solely or primarily concerned with trade liberalization, then the goal of the transparency provisions 
within the multilateral trading system is limited to the protection of the expectations of traders by making trade more efficient, predictable and, in the end, more profitable. ${ }^{9}$ If the WTO's mandate is broader and more focused on development, however, then the scope of the transparency commitments must be broader than simply the protection of the expectations of private traders. In this broader context, transparency arguably facilitates inter alia, governmental accountability, the participation of civil society, and the promotion of the right to due process in the administration of justice. This chapter assumes that the mandate of the WTO is in a state of flux: trade liberalization remains the animating principle of the multilateral trading system, but the WTO has no choice but to address simultaneously the broader development goals of the developing world and the complicated regulatory system of the developed world.

In view of the uncertainty surrounding the mandate of the WTO, this chapter focuses on the transparency commitments in the WTO covered agreements as interpreted and applied by the panels and the Appellate Body of the WTO Dispute Settlement Body (DSB). ${ }^{10}$ This chapter will first identify a few of the major transparency provisions of the WTO covered agreements. Second, it will analyze the application of transparency commitments in selected trade disputes before WTO panels and the Appellate Body. Last, drawing from the first two sections, the chapter will discuss three attributes of WTO transparency commitments in the context of the multilateral trading system: (1) the facilitation of trade disputes by making governmental measures transparent through publication and notification; (2) the reinforcement of central-government control of local, provincial or regional governments; and (3) the privileging of uniformity in substance and administration of measures within and among Member States."

\section{TRANSPARENCY AND THE MULTILATERAL TRADING SYSTEM}

Transparency is defined generally as the "sharing [of] information or acting in an open manner" or "a measure of the degree [to] which information about official activity is made available to an interested party."'12 In the WTO context, transparency provisions focus on procedural due process ${ }^{13}$ - publication, access to and flow of information, and independent judicial review-so as to allow private traders to prepare ahead of time for any risks or challenges that they may encounter. ${ }^{14}$ In addition to assisting private traders, transparency is also a criterion for "good governance," i.e., the "process of decision-making by governments and the process by which decisions are implemented."Is Even if we assume that the WTO's 
mandate is limited to promoting procedural due process for the benefit of private traders, the due process and transparency provisions of the WTO implement the model of good governance that seeks uniformity and harmonization.

\section{GATT 1947 and Transparency}

The United States proposed the language that ultimately became the transparency provision of GATT 1947: Article X (Publication and Administration of Trade Regulations) (See Appendix A). ${ }^{16}$ Article X traces its origin in part to the 1923 International Convention Relating to the Simplification of Customs Formalities, ${ }^{17}$ but it was also greatly influenced by the U.S. Administrative Procedures Act (APA), ${ }^{18}$ which had just been passed in the U.S. Congress. ${ }^{19}$ The United States proposed Article $\mathrm{X}$ in order to level the playing field for U.S. traders who faced opaque and informal administrative structures in importing countries, particularly as U.S. administrative processes had become more transparent for foreign traders interested in conducting business in the United States.

Article $X$ requires that all "laws, regulations, judicial decisions and administrative rulings of general application" (collectively "measures") be "published promptly in such manner as to enable governments and traders to become acquainted with them." 20 Article X:2 requires that measures be enforced only after they have been officially published, and according to Article $X: 3(a)$, such measures must be administered in a "uniform, impartial and reasonable manner."2l Lastly, under Article X:3(b), Member States "shall maintain, or institute as soon as practicable, judicial, arbitral or administrative tribunals or procedures for the purpose, inter alia, of the prompt review and correction of administrative action relating to custom matters." Such review shall be conducted by agencies that are independent from the administering agency involved. ${ }^{22}$

The signatories to the GATT viewed Article $\mathrm{X}$ as a procedural provision lacking in substantive force, and for this reason, they adopted it without any discussion or amendment. In fact, at the time of enactment, a senior Canadian negotiator is quoted as stating that Article $X$ contained no additional substantive requirements and, therefore, should not be of any concern to GATT Contracting Parties. ${ }^{23}$ Consistent with this view, GATT panels make no reference to Article $\mathrm{X}$ in any adopted dispute report from 1947 to 1984.

Then, starting in 1984, the United States began to invoke Article X after U.S. businesses were unable to gain access to the Japanese domestic market and started to face fierce competition from Japan in the U.S. domestic market. Targeting informal channels of communication maintained by 
the Japanese Government, the United States focused its Article X claims on the use of "administrative guidance." Such non-binding guidance served very effectively to exclude imports while the Japanese Government maintained that the guidance did not constitute governmental measures. ${ }^{24}$ In three adopted GATT 1947 panel reports, the GATT panels found that the practice of administrative guidance constituted "a measure" within the meaning of Article XI of GATT 1947 (Elimination of Quantitative Restrictions) that was inconsistent with the requirements of that provision. The GATT panels also stated that it was not necessary to address transparency claims under Article $X$, such as lack of publication or independent judicial review, because the measure itself was found to be GATTinconsistent regardless of whether it had been published. ${ }^{25}$ From 1947 to 1995 , only one adopted GATT panel found a violation of Article X. ${ }^{26}$

\section{WTO and Transparency}

With the creation of the WTO in 1995, Article X of GATT 1947 became Article X of GATT 1994 without any amendments or clarifications. Article $\mathrm{X}$ became incorporated and cross-referenced in: (1) an agreement that addresses procedures for customs valuation, i.e., the Agreement on Implementation of Article VII of the GATT 1994 (Customs Valuation Agreement); $;{ }^{27}$ (2) procedures for determination of the origin of a good for customs purposes (Agreement on Rules of Origin); $;^{28}$ and (3) procedures necessary for emergency action in order to prohibit serious economic injury including dislocation and unemployment of workers (Agreement on Safeguards). ${ }^{29}$ Other GATT 1994 Annex 1A covered agreements do not explicitly incorporate Article $\mathrm{X}$, but they contain many due process and transparency-related provisions addressing internal and border measures. Transparency and due process provisions exist throughout these agreements, including but not limited to, sanitary and phytosanitary measures (such as measures addressing food safety and pest control (SPS Agreement)); ${ }^{30}$ technical regulations or voluntary and non-binding standards (TBT Agreement); ${ }^{31}$ administration of border measures, such as licensing procedures; ${ }^{32}$ and administration of trade remedies such as antidumping and countervailing duties (SCM Agreement). ${ }^{33}$ The provisions of these agreements require Member States to notify the WTO that they intend to pass new legislation or to change existing legislation so that other countries may provide comment before the legislation goes into effect. ${ }^{34}$

Transparency is also a fundamental obligation under the GATS, which covers trade in services. Article III of the GATS (Transparency) largely follows the language of Article X of the GATT 1994 in that it requires publication of all relevant measures, including international agreements 


\section{Research handbook on transparency}

affecting trade in services. ${ }^{35}$ Article III also requires that WTO Members annually inform the WTO Council for Trade in Services of both any changes made to the laws that affect trade in services and the commitments that each Member has made under the GATS. Lastly, under Article III, all Member States must "establish one or more enquiry points to provide specific information to other Members." ${ }^{36}$ Rounding out its transparency commitments, Article VI of the GATS then requires Members to maintain "judicial, arbitral or administrative tribunals" to review administrative decisions affecting trade in services. ${ }^{37}$

Article 63 of the TRIPS also features similar transparency commitments. Paragraph 1 requires that WTO Members publish their intellectual property laws and regulations "in such a manner as to enable governments and right holders to become acquainted with them." 38 Under Paragraph 2, Member States must notify these laws and regulations to the Council for TRIPS "in order to assist that Council in its review of the operation of this Agreement." ${ }^{39}$ In addition, Article 63(3) allows Members to object to another Member's specific judicial and administrative rulings in the area of intellectual property and to request detailed written justification for the ruling. ${ }^{40}$

Finally, the Trade Policy Review Mechanism (TPRM) of the WTO issues periodic reports on each of the WTO Member States. ${ }^{41}$ The TPRM reports describe governmental policies and identify those procedures in need of greater transparency. The TPRM also encourages domestic transparency, which goes beyond the transparency of trade-related measures that is a substantive requirement of the WTO agreements. Part B of the TPRM addresses domestic (or internal) transparency:

Domestic Transparency-Members recognize the inherent value of domestic transparency of government decision-making on trade policy matters for both the Member's economies and the multilateral trading system, and agree to encourage and promote greater transparency within their own systems, acknowledging that the implementation of domestic transparency must be on a voluntary basis and take account of each Member's legal and political systems. ${ }^{42}$

In addition to the foregoing commitments, some WTO Member States have additional transparency commitments in their Protocols of Accession. Perhaps the best-known additional transparency commitments are those featured in the Protocol of Accession of China (see Appendix B) ${ }^{43}$ In addition to the transparency provisions applicable to all WTO Members, the Chinese Protocol of Accession requires, inter alia, that China (1) enforce only those laws, regulations, and trade-related measures that "have been first published and made available to WTO Members upon their request;" ${ }^{44}(2)$ "designate or establish an official journal" for the 
publication of all trade-related measures and after publication to "provide a reasonable period for comment," 45 and publish journals that are available "on a regular basis and make copies of all issues" that are readily available to individuals and enterprises; ${ }^{46}$ (3) "establish or designate, an enquiry point where, upon request of any individual, enterprise or WTO Member, all information relating to the measures required to be published ... may be obtained," and to provide replies to requests for information within 30 days (or 45 days given exceptional circumstances); ${ }^{47}$ (4) establish impartial and independent tribunals, contact points and procedures for the prompt review of all administration actions and trade-related measures under Article X:1 of GATT 1994, Article VI of GATS and relevant provisions of TRIPS;4 and (5) "provide opportunity for appeal, without penalty, by individuals or enterprises" and ultimately "right of appeal," requiring written decisions with appellants informed at every level of any right to further appeal. ${ }^{49}$

The WTO, specifically its transparency provisions, envisions a central government that maintains control over provincial and municipal governments. Such increased centralization is an inevitable consequence of the transparency commitments in the WTO covered agreements. China's accession to the WTO has not only liberalized (relatively speaking) foreign trade and investment regimes by making them less opaque, but also facilitated internal rule-of-law reforms that are consistent with Beijing's economic and social policies. ${ }^{50}$

\section{TRANSPARENCY IN WTO DISPUTE SETTLEMENT}

WTO dispute settlement panels and the Appellate Body have directly addressed Article $X$ and similar transparency claims, and in doing so, they have emphasized the importance of such provisions. Unlike GATT 1947 panels, WTO panels have not viewed Article X claims as ancillary to substantive claims. ${ }^{\text {s1 }}$ As early as 1997, the Appellate Body held that provisions of Article X, particularly Article X:2:

may be seen to embody a principle of fundamental importance-that of promoting full disclosure of governmental acts affecting Members and private persons and enterprises, whether of domestic or foreign nationality. The relevant policy principle is widely known as the principle of transparency and has obviously due process dimensions. The essential implication is that Members and other persons affected, or likely to be affected, by governmental measures ... should have a reasonable opportunity to acquire authentic information about such measures and accordingly to protect and adjust their activities or alternatively to seek modification of such measures. ${ }^{52}$ 
Notably, the Appellate Body Report that was adopted by the WTO membership states that Article $X$ requires governments to be transparent, not only with international or cross-border traders, but also with their own domestic traders. The Appellate Body emphasizes that Article $\mathrm{X}$ is explicitly concerned with the rights and expectations of traders, both domestic and international, as affected by governmental action. ${ }^{53}$ The Appellate Body has held that the transparency principles of Article $\mathrm{X}$ are even more important in cases where the measure violates WTO commitments but is justified as an exception due to other important public policy concerns, such as human life and health or the conservation of an exhaustible natural resource. $^{54}$

For example, in United States - Import Prohibition of Certain Shrimp and Shrimp Products (US - Shrimp), Section 609 of the Endangered Species Act (ESA) prohibited the importation of shrimp into the United States where the shrimp were caught using methods that resulted in a high mortality of sea turtles. ${ }^{55}$ Exporting nations seeking exemption from the import ban needed to certify either that they had conducted shrimp fishing in an environment that did not pose a threat to the "incidental taking of sea turtles," or that the "incidental taking of sea turtles" was comparable to that taking place in the United States. ${ }^{56}$ The Appellate Body held that Section 609 , on its face, was provisionally justified as an exception to the WTO market access and non-discrimination principles because it was primarily aimed at conserving an exhaustible natural resource, i.e., sea turtles. ${ }^{57}$ Nevertheless, the Appellate Body also held that Section 609 was applied in a discriminatory manner that was both "arbitrary" and "unjustifiable." 58 The application was deemed to be "contrary to the spirit, if not the letter, of Article X:3[.]"59

In compliance proceedings a few years later, the modifications made by the United States to the certification process, coupled with the United States' good faith efforts to conclude a multilateral agreement, met the requirements of the chapeau to Article XX (General Exceptions - see Appendix C). So long as the conditions enumerated in its report remained satisfied, the Appellate Body held that the United States no longer applied its certification process in an arbitrary or unjustifiable manner, and as a result, the United States could restrict importation of shrimp in order to protect sea turtles. ${ }^{60}$

In the US - Shrimp decision and others like it, the WTO has recognized that non-trade concerns (such as the environment) may, at times, trump the market access goals of the multilateral trading system. In the balancing act between trade and other important values, such as the environment or human health, Member States have used the concept of transparency both to challenge and to justify otherwise WTO-inconsistent measures. In the 
following section, we examine three attributes of the WTO transparency commitments by concentrating on selected Article $\mathrm{X}$ cases.

\section{THREE ATTRIBUTES OF TRANSPARENCY IN THE WTO CONTEXT}

An analysis of disputes invoking the transparency provisions of the WTO covered agreements reveals that Member States-regardless of their level of development, structure of government, or approach to transparency in governance-have failed to maintain measures consistent with the transparency obligations they have undertaken. Such failure to comply with the transparency obligations has resulted in increased litigation at the WTO level. Compliance with the WTO transparency obligations requires a strong central government that is able to supervise its provincial counterparts and to oversee the administration of rules throughout its territory. Compliance with the WTO covered agreements has also evidenced a close link between increased transparency and the push towards uniformity, harmonization, and convergence between and among regulatory structures.

\section{Increased Litigation}

Since the adoption of the Marrakesh Agreement in 1994, the WTO DSB has settled close to thirty disputes ${ }^{61}$ involving challenges brought under Article X of the GATT $1994 .{ }^{62}$ Several Article X disputes, including some still at the consultation phase, feature the United States, the European Union, and China as parties. ${ }^{63}$ For example, as China has incrementally adapted its legal and administrative framework to meet the WTO-plus transparency obligations contained in its Protocols of Accession, it has filed several Article X claims against the United States, arguably the very architect of the WTO transparency doctrine. ${ }^{64}$

In United States - Countervailing and Anti-Dumping Measures on Certain Products from China, ${ }^{65}$ China argued that the United States' enactment of a law to apply the countervailing duty provisions of the U.S. Tariff Act of 1930 to nonmarket (NME) economies (Public Law 112-99) ${ }^{66}$ is, as such, inconsistent with Articles X:1, X:2, and X:3(b) of the GATT 1994. Public Law 112-99 amends Section 701 of the U.S. Tariff Act of 1930 by allowing countervailing duties to be imposed on merchandise imported or sold for importation into the United States from an NME country. ${ }^{67}$ Public Law 112-99 made all countervailing duties imposed on or after November 20, 2006 applicable to this new law even though the law was published on March 13, 2012. ${ }^{68}$ As a result, China claimed that Public Law 112-99 (1) 
was not published promptly and was made effective prior to its publication in violation of Article X:1, ${ }^{69}$ that (2) it effected "an advance in a rate of duty ... on imports under an established and uniform practice" and imposed "a new or more burdensome requirement ... on imports" in violation of Article $\mathrm{X}: 2,{ }^{70}$ and that (3) it was amended retroactively such that judicial tribunals and procedures would no longer "govern the practice of [administrative] agencies" in violation of Article X:3(b). ${ }^{71}$

Ultimately, the panel decided that the United States did not act inconsistently with Articles X:1, X:2 or X:3(b).$^{72}$ A close analysis of the panel decision in this dispute is beyond the scope of this chapter; however, it should be noted that the panel engaged in an unprecedented discussion of Article $\mathrm{X}$, and it portends the continuation of a future trend of increased litigation in this regard. The general transparency provisions of Article $\mathrm{X}$ were deemed to be applicable to a measure that is also simultaneously subject to the procedural fairness and transparency requirements of another WTO covered agreement: the Agreement on Subsidies and Countervailing Measures. The panel's findings may be appealed by either the United States or China-or by both parties-to the Appellate Body.

China's active role in the WTO dispute settlement process is indicative of a wider trend among developing countries that have filed complaints against the United States, alleging that the United States' trade-related measures are inconsistent with the transparency provisions in the WTO covered agreements. ${ }^{73}$ Prior to China's request for consultations filed on September 17, 2012, ${ }^{74}$ Vietnam filed a request for consultations against the United States on February 20, 2012. ${ }^{75}$ As recently as July 12, 2013, the WTO DSB composed a panel for a case in which Vietnam asserted, inter alia, that the United States violated GATT Article X:3(a) as well as elements of the WTO Anti-Dumping Agreement for its failure to adhere to due process and procedural fairness in its evaluation of anti-dumping cases, particularly in the United States' use of its zeroing methodology, as well as its application of adverse facts available to its dumping margins. ${ }^{76}$ A report has not yet been issued in this dispute, but now that a panel has been composed, the matter will likely go forward unless the United States and Vietnam agree to settle the dispute bilaterally.

Notably, China and Vietnam are not alone in claiming that the United States administers its trade remedy laws in violation of Article X. In September 2012, Argentina also filed a dispute against the United States concerning alleged violations of, inter alia, GATT Article X." Alleging violations of Articles X:1 and X:3, Argentina argues in United States - Measures Affecting the Importation of Fresh Lemons that the United States' failure to publish a proposal for the amendment of the U.S. import approval process to authorize the entry of lemons from the Northeast 
region of Argentina constitutes a violation of Article X. ${ }^{78}$ Argentina claims that seven years have passed since the adoption of the CFR regulations governing the U.S. import approval process and that the failure of the United States to issue the relevant proposal constitutes an undue delay. ${ }^{79}$ The list of WTO Member States that have filed Article X claims against the United States, adjudicated or not, goes on to include, but is not limited to, Australia, Brazil, Canada, Chile, the European Communities, India, Indonesia, Japan, Mexico, New Zealand, Norway, the Republic of Korea, Switzerland, and Thailand. ${ }^{80}$

Increased litigation has also resulted from the willingness of panels to examine measures that are otherwise consistent with the substantive provisions of the WTO covered agreements. In China - Measures Related to the Exportation of Various Raw Materials (China - Raw Materials), discussed below, ${ }^{81}$ the panel concluded that Article X obligations relating to export quotas of various raw materials are "distinct from and additional to" those obligations that both relate to Article XI (General Elimination of Quantitative Restrictions) and are justified under an exception contained in the paragraphs of Article XX (Appendix C) ${ }^{82}$ The panel stated that even if a quota is justified pursuant to Article $\mathrm{XX}$, the allocation and administration of export quotas must comply with the procedural obligations inherent in Article X ${ }^{83}$ For this reason, the panel declined to exercise judicial economy as to the complainants' claims under Article X. ${ }^{84}$ China did not appeal this case to the Appellate Body, so the panel's statement in this regard remains unchallenged.

The panel's application of Article X to Article XX in China-Raw Materials is consistent with the Appellate Body ruling in US - Shrimp. ${ }^{85}$ According to the Appellate Body in US - Shrimp, paragraphs (a)-(j) of Article XX comprise measures that are eligible for limited and conditional exceptions to substantive obligations in the GATT 1994 because the domestic policies embodied in such measures have been recognized as important, legitimate in character, and capable of justifying an otherwise WTO-inconsistent measure..$^{86}$ Nevertheless, the exceptional measure must meet a high standard of transparency and due process by making certain that the restriction is not applied in an 'arbitrary' or 'discriminatory' manner or as a 'disguised restriction on international trade' ${ }^{87}$ The Appellate Body stated in US - Shrimp:

Inasmuch as there are due process requirements generally for measures that are otherwise imposed in compliance with WTO obligations, it is only reasonable that rigorous compliance with the fundamental requirements of due process should be required in the application and administration of a measure which purports to be an exception to the treaty obligations of the Member imposing the measure and which effectively results in a suspension pro hac vice of the treaty rights of other Members. 
The Appellate Body stressed that Article X:3 establishes "certain minimum standards for transparency and procedural fairness in the administration of trade regulations" that the United States' certification process failed to achieve. ${ }^{89}$ As stated previously, the Appellate Body determined in subsequent proceedings that the United States applied its measure in a transparent and even-handed manner after it made changes to the certification process and attempted in "good faith" to negotiate a multilateral agreement for the protection and preservation of sea turtles.

In sum, WTO transparency commitments-such as those addressing publication, notification, due process and independent judicial reviewprovide an additional basis upon which a Member State may challenge a law, rule, or judicial/arbitral decision before WTO panels and the Appellate Body. Indeed, transparency in the application or administration of measures has increasingly become a secondary - and, at times, the primarylegal basis for a dispute. ${ }^{90}$ WTO obligations have come increasingly into conflict with other substantive areas of public policy, such as protection and preservation of the environment or human health. Such non-trade objectives, according to the Appellate Body, can only be justified as an exception under Article XX or be viewed as a legitimate form of non-tariff trade barrier, if they are applied in a manner that also respects the values of transparency and fundamental due process as expressed in Article X and other transparency provisions of the WTO covered agreements.

\section{Increased Centralization}

The WTO envisions a strong central government, particularly in the implementation of the transparency obligations in its covered agreements. Article XVI of the WTO Charter requires that each Member "ensure the conformity of its laws, regulations and administrative procedures with its [WTO] obligations[.]"91 As a result, many WTO covered agreements require conformity of measures throughout the territory of a Member State. For example, Article 3 of the TBT Agreement mandates conformity by local and non-governmental bodies under the supervision of central governments. ${ }^{92}$ Member States are obligated to take reasonable measures to ensure compliance by local and non-governmental bodies with the provisions of Article 2 of the TBT Agreement, ${ }^{93}$ and Member States must ensure that "technical regulations of local governments on the level directly below that of the central government in Members are notified in accordance with the [substantive provisions of the TBT Agreement]." 94

The push toward centralization of rule making has been the focus not only of the WTO agreements, but also of WTO disputes. In China - Raw Materials, the European Union, the United States, and Mexico challenged 
China's allocation of export zinc quotas and its imposition of export restrictions and export taxes on certain raw materials, including zinc. ${ }^{95}$ China's Ministry of Commerce (MOFCOM) had promulgated Article 19 of the Export Quota Administration Measures, which stated that an export quota for zinc may be refused on the basis of "operation capacity" criteria, ${ }^{96}$ but the measure did not go into detail as to the manner in which the "operation capacity" would be determined. ${ }^{97}$ As a result, the 32 Local Departments in charge of foreign trade were left to interpret and administer the "operation capacity" criteria as they deemed appropriate. ${ }^{98}$ China justified its "operation capacity" requirement on the basis that there would be no point in allocating part of the export quota to an applicant if that applicant did not have "the operational ability to engage in export trade, which implicates sophisticated financing questions often not present in domestic trade[.]"'99

In its ruling, the panel widened the scope of Article $X: 3(a)$ in a way that potentially emphasized the burden on central governments to ensure conformity of provincial and municipal governmental measures with WTO rules. Citing to the Panel Report in Argentina - Hides and Leather, the China - Raw Materials panel stressed that the obligations of uniformity, impartiality, and reasonableness "are legally independent from one another and WTO Member States are obliged to comply with all three requirements." 100 According to the panel, a finding of a violation of any of the above obligations would constitute a violation of Article X:3(a) in its entirety. ${ }^{101}$

Turning to the facts of the case, the panel then concluded that the lack of definition, guidelines, or standards in the application of the "operation capacity" criterion by the 32 Local Departments posed "a very real risk to the interests" of other WTO Member States such that it would necessarily result in unreasonable and non-uniform administration inconsistent with Article X:3(a) of the GATT 1994. ${ }^{102}$ Citing to the Appellate Body Decision in EC-Customs (discussed below), ${ }^{103}$ the panel in China - Raw Materials then noted that differences existing at the level of administrative processes can be so "significant" to the extent that they "have caused, or are likely to cause," unreasonable application of the export quota administration measure. ${ }^{104}$

However, in the panel's estimation, unreasonable application or lack of uniformity did not constitute partiality. The panel held that while nonuniformity leads to unreasonable administration, it does not necessarily lead to partial administration. ${ }^{105}$ As a result, the panel was not convinced "that the lack of any definition, guidelines or standards in how the 32 Local Departments should interpret the term 'operation capacity' will pose a very real risk that such partial administration would necessarily result[.]"106 
Centralization is essential for uniformity, and uniformity, not partiality, is the basis for reasonable administration. In sum, the WTO rules empower a central government and make it responsible for harmonizing the activities of the local governments so as to ensure that they are uniform. It is interesting to ask, then, what is the value of uniformity alone-other than reducing the cost of doing business--that lack of it is deemed unreasonable even when there is no discrimination? For that reason, we turn now to the third impact of transparency: increased uniformity.

\section{Increased Uniformity}

The WTO promotes uniformity through harmonization of laws and deference to international standards. In situations where international standards do not yet exist, the WTO turns to the concept of transparency in administration. This approach is consistent with the text of the agreements, including, but not limited to, the TBT and SPS Agreements. In promoting predictability in the trading system and safety of goods in cross-border transactions, ${ }^{107}$ the TBT Agreement promotes uniformity of technical regulations in so far as they are based on international standards. ${ }^{108}$ Article 2.4 of TBT Agreement states that:

[w] here technical regulations are required and relevant international standards exist or their completion is imminent, Members shall use them, or the relevant parts of them, as a basis for their technical regulations except when such international standards or relevant parts would be an ineffective or inappropriate means for the fulfillment of the legitimate objectives pursued, for instance because of fundamental climatic or geographical factors or fundamental technological problems. ${ }^{109}$

Diversity in the application of standards is encouraged only to the extent that WTO Member States deem international standards to be insufficient in the pursuit of their legitimate objectives. ${ }^{110}$ Moreover, according to Article 2.5, "[w]henever a technical regulation is prepared, adopted or applied for one of the legitimate objectives explicitly mentioned in paragraph 2, and is in accordance with relevant international standards, it shall be rebuttably presumed not to create an unnecessary obstacle to international trade." 111 Hence, WTO Member States are encouraged to follow international standards.

While the TBT Agreement stresses adoption of, and adherence to, international standards, the SPS Agreement places particular emphasis on harmonization of sanitary and phytosanitary measures. ${ }^{112}$ SPS Article 3.1 provides that WTO Member States "shall base their sanitary and phytosanitary measures on international standards, guidelines, or recom- 
mendations, where they exist[,]" 113 and according to Article 3.2, "[s]anitary or phytosanitary measures which conform to international standards, guidelines, or recommendations shall be deemed to be necessary to protect human, animal, or plant life or health, and presumed to be consistent with the relevant provisions of this Agreement and of GATT 1994."114 The SPS Agreement promotes harmonization of standards, in particular among the "three sister" organizations listed in Article 3.4: the Codex Alimentarius Commission, the Office International des Epizooties, and the Secretariat of the International Plant Protection Convention. ${ }^{115}$ Under Article 3.2, WTO Member States are required to play an active part in promoting the development and review of standards within these three organizations. ${ }^{116}$

WTO jurisprudence furthers the emphasis of uniformity presented in the covered agreements. The trend toward uniformity became paramount in European Communities - Selected Customs Matters (EC - Selected Customs Matters). In that case, the United States claimed that the European Communities had failed to administer uniformly-both through individual laws and as a whole, its system of customs administration as it related to the classification, valuation, and certain restrictions of products under Article X:3(a) of the GATT 1994. ${ }^{117}$ The Appellate Body widened the scope of Article $\mathrm{X}$ by blurring the distinction between administrative challenges-those addressing the lack of due process, procedural fairness, or transparency in the administration or application of a measure-and substantive challenges-those addressing the consistency of the substance or text of a provision with WTO obligations. ${ }^{118}$

In its analysis of the United States' claims, the Appellate Body in EC - Selected Customs Matters made three findings that arguably moved the WTO DSB ${ }^{119}$ in the direction of greater uniformity in the administration and substance of trade-related measures. First, the Appellate Body emphasized that "nothing in the DSU or other WTO agreements would prevent a complaining Member State from challenging a Member's system 'as a whole or overall" without reference to particular inconsistent application of a measure in a particular case. ${ }^{120}$ This finding perhaps motivated the European Union to file its complaint against China in the China - Various Raw Materials case, and it may encourage other WTO Member States to file similar claims. Second, the Appellate Body held that the traditional administrative-substantive distinction (as developed in EC-Bananas III and $E C$ - Poultry) ${ }^{121}$ did not exclude the possibility of allowing challenges to the substance of a measure under Article X:3 if such measure necessarily leads to an inconsistent application-a non-uniform, partial, or unreasonable application - of the measure. ${ }^{122}$ Last, the Appellate Body found that Article X:3(b) requires a WTO Member State "to establish and maintain independent mechanisms for prompt review and correction 
of administrative action in the area of customs administration."123 As a result, WTO Member States may now challenge the existing structure of the custom review mechanism "as is" without reference to specific application to private traders. ${ }^{124}$

Quoting from the EC-Selected Customs Matters case, the Appellate Body in Thailand - Customs and Fiscal Measures on Cigarettes from the Philippines (Thai - Cigarettes) affirmed the basic object and purpose of the GATT as embodied in Article X:3(b): to ensure due process in relation to customs matters, or more specifically, "to ensure that a trader who has been adversely affected by a decision of an administrative agency has the ability to have that adverse decision reviewed." 125 The Appellate Body recognized that, under Article X:3(b), WTO Members have the discretion to design and administer their own laws and regulations so long as such administration "afford[s] the protection of due process to individual traders" by maintaining tribunals or procedures for the prompt review and correction of administrative action. ${ }^{126}$ In sum, the Appellate Body has reaffirmed numerous times that the justification for uniformity and increased procedural transparency is to the benefit of private traders. It has been largely reluctant to endorse explicitly the value of such transparency commitments beyond the benefit of private traders and to address potential broader societal and development goals of transparency. At the same time, the Appellate Body has stated that Article X does "embody a principle of fundamental importance" and, in doing so, acknowledges the value of transparency outside of the context of trade.

\section{CONCLUSION}

The mandate of the WTO remains unclear. While some WTO Member States have argued that the goal of the WTO is sustainable development, others seek to limit the focus of the WTO to trade liberalization. How one sees the WTO will also determine the scope of its transparency commitments. So far, WTO panels and the Appellate Body have explicitly stated that the WTO transparency provisions are designed to protect the expectations of private traders. Yet, the WTO transparency obligations cannot be immune from the broader discourse on transparency and its role in development, good governance, and the promotion and preservation of rule of law. Indeed, through TPRM, the WTO does promote domestic transparency separate and apart from transparency that is designed to protect expectations of private traders. ${ }^{127}$ The transparency commitments of the multilateral trading system have had, and continue to have, significant impact on internal governance of Member States, particularly newly 
acceding WTO members. For example, the WTO has had a profound impact on China in so far as it has facilitated greater transparency of laws and has further legitimated the reforms that the Chinese Government may have wanted to pursue independent of its compliance with WTO rules.

In sum, the application of transparency in the WTO context has three attributes. First, transparency facilitates trade disputes by identifying measures whose application and administration are inconsistent with the provisions of the covered agreements. Second, transparency promotes the power of the central governments within each Member State over local or provincial governments. Third, transparency requires uniformity, to the extent feasible, in administration of measures within and among Member States.

Apart from securing the interest of private traders, questions remain as to whether these three attributes contribute to the broader goals of transparency. Does the push toward centralization and uniformity of rule making in Member States, such as China, advance democratic ideals and good governance, such as participation and accountability? Is there any downside to the loss of control and discretion by local authorities? Does centralization make governance expensive and inefficient? Moving forward, it is necessary to examine the potential downsides of the trend towards greater uniformity and the loss of control or discretion by local authorities that is being promoted in the name of, and in the pursuit for, greater transparency.

\section{NOTES}

1. In the WTO context, transparency of the institution itself is an issue in terms of participation and access to information, but that issue is not discussed here. See generally Steve Charnovitz, Transparency and Participation in the World Trade Organization, 56 RUTGERS L REv. 927.

2. Initial GATT dispute resolution provisions, encompassed in Articles XXII and XXIII, required only bilateral consultations and sympathetic consideration to the complaints of a GATT contracting party whose expectations of a competitive relationship had been injured. If bilateral consultations had failed, the complainant could seek consultations on a multilateral level with the GATT contracting parties, who were required to investigate the complaints and recommend an appropriate solution to the matter as provided by GATT governing rules and procedures. These consultations consisted of careful negotiations, the assertion of political power, and the voluntary cooperation of the GATT contracting parties. In the event that a dispute was to go before a GATT panel and the panel was to issue a report, the report would not be adopted unless all GATT contracting parties had agreed to it. See, e.g., Michael K. Young, Dispute Resolution in the Uruguay Round: Lawyers Triumph over Diplomats, 29 J. INT'L L. 389, 392-404 (1995); Jeffrey Waincymer, Transparency of Dispute Settlement within the World Trade Organization, 24 MelB. U. L. Rev. 797, 798 (2000); Petko D. Kantchevski, The Differences Between the Panel Procedures of the GATT and the WTO: The Role 
of GATT and WTO Panels in Trade Dispute Settlement, 3 INT'L L. \& MGMT. Rev. 79, 79-91, 94-100 (2006).

3. See John H. JACKsonet al., Legal Problems of International Economic Relations: Cases, Materials and TeXt 252-56 (4th ed. 2002) [hereinafter International. ECONOMIC RELATIONS) (outlining the progression from the GATT 1947, which resolved disputes through bilateral or multilateral negotiations and agreement relative to the power status of the parties, to the GATT 1994 and other WTO covered agreements, which settled disputes through consultations or panel hearings governed by norms or rules to which both parties have agreed); ibid. at 257-68 (highlighting that the GATT consensus-based system, which required unanimous consent among disputing parties to establish panels and to adopt panel reports, was replaced by the WTO rule-based system crystallized in the Dispute Settlement Body (DSB), which established procedures governing consultations, the formation of a panel, the adoption of a panel decision or appeal of the decision to the Appellate Body, and the implementation and suspension of concessions).

4. General Agreement on Trade in Services, Apr. 15, 1994, Marrakesh Agreement Establishing the World Trade Organization, Annex IB, The Legal Texts: ThE Results of the Uruguay Round of Multilateral Trade Negotiations 287-88, 290-91 (1999), 1869 U.N.T.S. 183.

5. Agreement on Trade-Related Aspects of Intellectual Property Rights, Apr. 15, 1994, Marrakesh Agreement Establishing the World Trade Organization, Annex 1C, The Legal Texts: The Results of the Uruguay Round of Multilateral Trade Negotiations 348 (1999), 1869 U.N.T.S. 299.

6. See Padideh Ala'i, Transparency and the WTO Mandate, 26 A.. U. INT'L L. Rev. 1009, 1029 (2011) [hereinafter Transparency and the WTO Mandate] (predicting that the WTO will focus increasingly on domestic transparency and predictability in the application of measures that are trade-restrictive or discriminatory but that, nevertheless, promote values important to sustainable development); see also Sylvia Ostry, China and the WTO: The Transparency Issue, 3 UCLA J. INT'L \& ForeIGN AFF. 1, 11 (1999) [hereinafter China and the WTO] (concluding that a lack of transparency within the administrative law regime of a country, such as China, frustrates the expectations of the increased legalization in international trade law, which should lead to deepening integration among WTO Member States).

7. Transparency and the WTO Mandate, supra note 6, at 1010-11. See Padideh Ala'i, From the Periphery to the Center? The Evolving WTO Jurisprudence on Transparency and Good Governance, in Redesigning the WorLd TRADE ORGaNIZATION fOR THE TWENTY-FIRST CENTURY 165, 169 [hereinafter From the Periphery to the Center] (stating that, by the mid 1980s, the United States became concerned about the proliferation of nontariff barriers, which came to include non-transparent and ad hoc administration of customs regulations).

8. Roberto Azevêdo, Azevêdo: WTO must keep development agenda, RoBERTo AztVÊDo: NEw WTO DiRECTOR-GENERAL (last visited Nov. 6, 2013), http://www.robertoazevedo. org/en/news-en/219-azevedo-wto-must-keep-development-agenda ("We cannot throw away the development agenda, so arduously negotiated in order to ensure the benefit of the poorest and most vulnerable members of the WTO. We cannot simply turn the page and leave them behind[.]").

9. Some have argued that the aim of the WTO is also to promote development, but what that means for the concept of transparency is unclear.

10. The WTO Dispute Settlement Understanding (DSU) outlines the procedural rules that govern the settlement of disputes between Member States. Understanding on Rules and Procedures Governing the Settlement of Disputes, Apr. 15, 1994, Marrakesh Agreement Establishing the World Trade Organization, Annex 2, The Legal Texts: The Results of the Uruguay Round of Multilateral. Trade Negotiations 355 (2003), 1869 U.N.T.S. 401, 33 I.L.M. 1226 (1994). Member States have the right to request the establishment of a panel of three persons to preside over a dispute between 
them. Ibid. arts 6, 8. The panels do not issue binding decisions: they make appropriate recommendations and rulings for the settlement of the dispute, usually relating to the consistency of a measure with a WTO covered agreement based on an objective assessment of the facts of a case. Ibid. arts 11, 19. The parties to the dispute may appeal the panel findings to the Appellate Body in order to have issues of law and the panel's legal interpretation reviewed. Ibid. art. 17.

11. For more information concerning the importance and development of global administrative law, see generally The Global Administrative Law Project, N.Y.U. ScHOOL of LAW, INSTITUTE FOR INTERNATIONAL. LAW AND JUSTICE (last visited Oct. 13, 2013), http://www.iilj.org/gal/.

12. See William Mock, On the Centrality of Information Law: A Rational Choice Discussion of Information Law and Transparency, 17 J. MARSHALL J. COMPUTER \& INFO. L. 1069, 1182 (1999).

13. See From the Periphery to the Center, supra note 7, at 166 (clarifying that the focus of transparency is on procedural due process: publication, access to and flow of information, and independent judicial review), 173 (highlighting the other Annex IA agreements that contain provisions addressing transparency and due process in the administration of measures, including but not limited to the Agreement on the Application of Sanitary and Phytosanitary Measures, the Agreement on Technical Barriers to Trade, the Agreement on the Implementation of Article VI of the GATT 1994, and the Agreement on Subsidies and Countervailing Measures).

14. See Panel Report, European Communities - Selected Customs Matters, 77.191 , WT/ DS315/R (June 16, 2006) [hereinafter EC-Selected Customs Matters] (noting that the difficulties that the panel found in attempting to understand the EC system of customs administration "would be multiplied manifold for traders in general and small traders in particular who are trying to import into the European Communities"). See also infra discussion in the section entitled "Three Attributes of Transparency in the WTO Context: Increased Uniformity".

15. See United Nations Economic and Social Commission for Asia and the Pacific (ESCAP), What is Good Governance?, http://www.unescap.org/pdd/prs/Project Activities/Ongoing/gg/governance.pdf (last visited Oct. 13, 2013). The term "good governance" includes five basic characteristics: (1) participation, (2) transparency, (3) responsibility, (4) accountability, and (5) responsiveness; Commission on Human Rights, Role of Good Governance in the Promotion of Human Rights, U.N. Doc. E/ CN.4/RES/2000/64 (Apr. 27, 2000). A strong argument can be made that the cumulative effect of the "good governance" provisions of the WTO, for example requiring notification, publication, participation, responsiveness, and access to information, have potentially far greater impact on domestic governance of states than direct attempts at legal and institutional reform by the World Bank, the International Monetary Fund (IMF) and others. A prominent example of the influence of WTO's transparency and good governance provisions is seen in the case of China, where thousands of pieces of legislation were promulgated in connection with China's accession to the WTO.

16. GATT 1994: General Agreement on Tariffs and Trade 1947, Apr. 15 1994, Marrakesh Agreement Establishing the World Trade Organization, Annex 1A, THE Legal Texts: The Results of the Uruguay Round of Multilateral Trade Negotiations 424 (1999), 1867 U.N.T.S. 187 [hereinafter GATT 1947]; General Agreement on Tariffs and Trade art. X, Oct. 30, 1947, 61 Stat. A-11, 55 U.N.T.S. 194.

17. See generally 1923 International Convention Relating to the Simplification of Customs Formalities arts 4 and 6, Nov. 3, 1923, 190 U.N.T.S. 253.

18. 5 U.S.C. $\$ 551-59$.

19. Article $X$ was originally Article 15 of the draft Charter of the International Trade Organization (ITO), but the ITO did not come to fruition as one of the three postWWII institutions created at the Bretton Woods, New Hampshire conference in July 1944 because the US failed to support its establishment. The other two Bretton Woods institutions-the International Monetary Fund (IMF) and the World Bank-did 
come into fruition and have helped to establish a framework for economic cooperation and development leading to a more stable global economy. Ostensibly, the IMF promotes international monetary cooperation, provides policy advice and technical assistance, makes loans, and helps countries to design policy programs to build and maintain strong economies. The World Bank promotes long-term economic development and poverty reduction by providing technical and financial support to help countries reform particular sectors or implement specific projects. Factsheet: The IMF and the World Bank. INT'L MONETARY FuND (Sept. 30, 2013), http://www.imf.org/ external/np/exr/facts/imfwb.htm.

20. GATT 1994 art. X:1.

21. Ibid., arts. $X: 1, X: 3(a)$.

22. Ibid., art. X:3(b). See infra Appendix A for complete text.

23. Sylvia Ostry, Article $X$ and the Concept of Transparency in the GATTIWTO, in CHINA and the Long March to Global Trade: The accession of China to the World Trade Organization 123-24 (Alan S. Alexandroff, Sylvia Ostry and Rafael Gomez (eds), UK: Routledge 2002). See also China and the WTO, supra note 6, at 4 . The GATT referred to states not as Members or Member States, but as "Contracting Parties," denoting the provisional status of the GATT as an agreement. See JACKSON, InTERNATIONAL ECONOMIC RELATIONS, at 257-68.

24. See, e.g. Report of the Panel, Japan - Measures on Imports of Leather,9716, 28, L/5623 (May 15, 1984) [hereinafter Japan - Leather] (cvaluating the United States' claim that the Japanese import leather quota system violated Articles $X: 1$ and $X: 3$ by failing to publish the total import quotas and certain administrative rulings related to it, as well as by allocating licenses so as to channel import trade through Japanese producers and distributors); Report of the Panel, Japan - Restrictions on Imports of Certain Agricultural Products, fL/6253 (Mar. 2, 1988) [hereinafter Japan - Agricultural Products $\Pi$ (considering the US' argument that Japan, in administering its quota system for certain agricultural products, violated Articles $X: 1$ and $X: 3$ by failing to "publish adequate and timely information on quota volume or value", which constituted an unreasonable administration of the import quota system in violation of Article X:3(a)); Report of the Panel, Japan - Trade in Semi-Conductors, \{135, L/6309 (May 4, 1988) [hereinafter Japan - Semi Conductors] (outlining the argument of the European Communities that Japan's administrative guidance controlled export prices, export volume, production volume and other aspects related to exports).

25. Report of the Panel, Japan - Leather, supra note 24,9744, 57; Report of the Panel, Japan - Agriculiural Products I, supra note 24, 5.4.2, 6.2; Report of the Panel, Japan Semi-Conductors, supra note 24, $7735,53,128$.

26. See Report of the Panel, European Economic Community - Restrictions on Imports of Dessert Apples - Complaint by Chile,\$12.29-.30, L/6491, (June 22, 1989) (ruling that the specific act of back-dating quotas on imports of dessert apples by the European Economic Community was inconsistent with the publication requirement of Article X, but finding that the requirement of "uniformity" in administration imposed by Article $X: 3(a)$ did not require EEC Members to have identical administrative procedures with regards to the import of dessert apples).

27. Agreement on Implementation of Article VII of the General Agreement on Tariffs and Trade 1994, art. 12, Apr. 15, 1994, Marrakesh Agreement Establishing the World Trade Organization, Annex IA, The Legal Texts: The Results of the Uruguay Round OF Multilateral TRade Negotiations 179 (1999), 1868 U.N.T.S. 279 (“Laws, regulations, judicial decisions and administrative rulings of general application giving effect to this Agreement shall be published in conformity with Article X of GATT 1994 by the country of importation concerned.").

28. Agreement on Rules of Origin, arts 2(f), 3(h), Apr. 15, 1994, Marrakesh Agreement Establishing the World Trade Organization, Annex IA, THE LeGal Texts: ThE Results of the Uruguay Round of Multilateral Trade Negotiations 212, 214-15 (1999), 1868 U.N.T.S. 397 (providing that any administrative action taken in relation to 
the determination of origin "is reviewable promptly by judicial, arbitral or administrative tribunals or procedures, independent of the authority issuing the determination, which can effect the modification or reversal of the determination").

29. Agreement on Safeguards art. 3, Apr. 15, 1994, Marrakesh Agreement Establishing the World Trade Organization, Annex 1A, The Legal Texts: The Results OF the URuguay Round of Multilateral Trade Negotiations 276 (1999), 1869 U.N.T.S. 154 (allowing a Member to apply for a safeguard measure "only following an investigation by the competent authorities of that Member pursuant to procedures previously established and made public in consonance with Article X of GATT 1994").

30. Agreement on the Application of Sanitary and Phytosanitary Measures, Apr. 15, 1994, Marrakesh Agreement Establishing the World Trade Organization, Annex 1A, The Legal Texts: The Results of the Uruguay Round of Multilateral Trade Negotiations 59 (1999), 1868 U.N.T.S. 493 [hereinafter SPS Agreement] ("Members shall notify changes in their sanitary or phytosanitary measures and shall provide information on their sanitary or phytosanitary measures in accordance with the provisions of Annex B.") See also infra discussion in the section entitled "Three Attributes of Transparency in the WTO Context: Increased Uniformity".

31. Agreement on Technical Barriers to Trade, Apr. 15, 1994, Marrakesh Agreement Establishing the World Trade Organization, Annex 1A, The Legal Texts: The Results of the Uruguay Round of Multilateral Trade Negotiations 121 (1999), 1868 U.N.T.S. 120 [hereinafter TBT Agreement]. See infra discussion in the section entitled "Three Attributes of Transparency in the WTO Context: Increased Uniformity".

32. Agreement on Import Licensing Procedures, Apr. 15, 1994, Marrakesh Agreement Establishing the World Trade Organization, Annex 1A, The Legal Texts: The Results of the URuguay Round of Multilateral Trade Negotiations 223 (1999), 1868 U.N.T.S. 436.

33. Agreement on Implementation of Article VI of the General Agreement on Tariffs and Trade, Apr. 15, 1994, Marrakesh Agreement Establishing the World Trade Organization, Annex 1A, The Legal Texts: The Results of the URuguay Round of Multilateral Trade Negotiations 147 (1999), 1868 U.N.T.S. 201; Agreement on Subsidies and Countervailing Measures, Apr. 15, 1994, Marrakesh Agreement Establishing the World Trade Organization, Annex 1A, The Legal Texts: The Results of the Uruguay Round of Multilateral Trade Negotiations 231 (2003), 1869 U.N.T.S. 14 [hereinafter SCM Agreement].

34. SPS Agreement, art. 7 ("Members shall notify changes in their sanitary and Phytosanitary measures and shall provide information on their sanitary or Phytosanitary measures in accordance with the provisions of Annex B."); TBT Agreement, art. 2.9 (stating that Member shall notify other Members through the Secretariat of the products to be covered by the proposed technical regulation, together with a brief indication of its objective and rationale); SCM Agreement, arts 25,26 (outlining the content, scope, and nature of notification that Member States must provide regarding specific subsidies and the surveillance that the Committee will conduct regarding new and full notifications).

35. GATS, art. III.

36. Ibid.

37. GATS, art. VI.

38. TRIPS, art. 63(1).

39. Ibid., art. 63(2).

40. Ibid., art. 63(3).

41. The Trade Policy Review Mechanism monitors "domestic transparency in government decision-making in the trade policy-making area."

42. The Legal Texts: The Results of the Uruguay Round of Multilateral Trade Negotiations 380 (2003).

43. Protocol on the Accession of the People's Republic of China, art. 2(C)(1), WT/L/432 
(Nov. 23, 2001). See infra Appendix B for complete text. Protocols of Accession contain the terms of accession agreed upon by the applicant and the members of the Working Party. How to become a member of the WTO, WORLD TRADE ORG. (last visited Nov. 6, 2013) http://www.wto.org/english/thewto_e/acc_e/acces_e.htm.

44. Ibid., art. $2(\mathrm{C})(1)$.

45. Ibid., art. 2(C)(2). An exception is provided for laws, regulations and measures involving national security and specific measures setting foreign exchange rates or monetary policy and other measures the publication of which would impede law enforcement.

46. Ibid., art. $8(1)(\mathrm{a})$.

47. Ibid., art. $2(\mathrm{C})(3)$.

48. Ibid., art. 2(D)(1)

49. Ibid., art. 2(D)(2).

50. See generally Julia Y. Qin, Trade, Investment and Beyond: The Impact of WTO Accession on China's Legal System, CHINA QuARTERLY 720 (2007).

51. Since the founding of the WTO there have been at least 50 disputes involving consideration of Article X. Moreover, more than one-third of those disputes have been filed against the US. See World Trade Organization, Dispute Settlement: Disputes by Agreement, http:/www.wto.org/english/tratop_e/dispu_e/dispu_agreements_index_e. htm?id=A9 (scroll to the bottom of the page, which lists Article $X$ cases in chronological order). See infra discussion in the section entitled "Three Attributes of Transparency in the WTO Context: Increased Litigation".

52. Appellate Body Report, United States - Restrictions on Imports of Cotton and Man-Made Fibre Underwear, 20, WT/DS24/AB/R (Feb. 25, 1997) [hereinafter US Underwear] (emphasis added).

53. Ibid.

54. Appellate Body Report, United States - Import Prohibition of Certain Shrimp and Shrimp Products, $\rrbracket 182$, WT/DS58/AB/R (Nov. 6, 1998) [hereinafter US - Shrimp].

55. Ibid., $\llbracket 2$.

56. Ibid.93.

57. Ibid., शा138-42.

58. Ibid., $7172-76,177-80$ (finding that the United States applied Section 609 in an arbitrarily and unjustifiably discriminatory manner because it (1) negotiated seriously with some countries but not others in establishing its requirements, (2) applied short phase-in periods within which some countries faced higher burdens in meeting the requirements, (3) made greater efforts to transfer TED technology to exporting countries, (4) adopted a rigid, inflexible regulatory program without determining whether the program was appropriate for the conditions prevailing in exporting countries, and (5) failed to make the certification process transparent, predictable, and appealable).

59. Ibid, $\$ 183$ (noting that the failure of the United States to institute a "formal legal procedure for review of, or appeal from, a denial of an application, are all contrary to the spirit, if not the letter, of Article X:3 of the GATT 1994").

60. Article 21.5 Appellate Body Report, United States - Import Prohibition of Certain Shrimp and Shrimp Products, 121-24, 134, 153, WT/DS58/AB/R (Oct. 22, 2001).

61. That number does not include other transparency-related provisions that have been invoked in numerous other disputes.

62. Panel Report, European Union - Anti-Dumping Measures on Certain Footwear from China, WT/DS405/R (Oct. 28, 2011) [hereinafter EU - Footwear]; Appellate Body Report, European Communities - Definitive Anti-Dumping Measures on Certain Iron or Steel Fasteners from China, WT/DS397/AB/R (July 15, 2011) [hereinafter Appellate Body Report, EC - Iron or Steel Fasteners]; Panel Report, European Communities - Definitive Anti-Dumping Measures on Certain Iron or Steel Fasteners from China, WT/DS397/R (Dec. 3, 2010) [hereinafter Panel Report, EC - Iron or Steel Fasteners]; Appellate Body Report, China - Measures Related to the Exportation of Various Raw Materials, WT/DS398/AB/R WT/DS395/AB/R, WT/DS394/AB/R (Jan. 30, 2012); Panel Report, China Measures Related to the Exportation of Various Raw Materials, 
WT/DS398/R, WT/DS395/R, WT/DS394/R (July 5, 2011) [hereinafter China Raw Materials]; Appellate Body Report, United States - Certain Country of Origin Labelling (COOL) Requirements, WT/DS386/AB/R, WT/DS384/AB/R (June 29, 2012); Panel Report, United States - Certain Country of Origin Labelling (COOL) Requirements, WT/DS386/R, WT/DS384/R (Nov. 18, 2011) [hereinafter US - COOL]; Appellate Body Report, Thailand - Customs and Fiscal Measures on Cigarettes from the Philippines, WT/DS371/AB/R (June 17, 2011) [hereinafter Thailand - Cigarettes]; Panel Report, Thailand - Customs and Fiscal Measures on Cigarettes from the Philippines, WT/DS371/R (Nov. 15, 2010); Panel Report, Colombia - Indicative Prices and Restrictions on Ports of Entry, WT/DS366/R (Apr. 27, 2009); Appellate Body Report, United States - Customs Bond Directive for Merchandise Subject to AntiDumping / Countervailing Duties, WT/DS345/AB/R (July 16, 2008); Panel Report, United States - Customs Bond Directive for Merchandise Subject to Anti-Dumping / Countervailing Duties, WT/DS345/R (Feb. 29, 2008) [hereinafter US - Customs Bond Directive]; Panel Report, United States - Measures Relating to Shrimp from Thailand, WT/DS343/R (Feb. 29 2008) [hereinafter US - Shrimp (Thailand)]; Appellate Body Report, China - Measures Affecting Imports of Automobiles, WT/DS342/AB/R (Dec. 15, 2008); Panel Report, China - Measures Affecting Imports of Automobiles, WT/ DS342/R (July 18, 2008); Appellate Body Report, European Communities - Selected Customs Matters, WT/DS315/AB/R (Dec. 11, 2006) [hereinafter Appellate Body, EC Selected Customs Matters]; Panel Report, EC - Selected Customs Matters, supra note 14; Panel Report, Turkey - Measures Affecting the Importation of Rice, WT/DS334/R, (Sept. 21, 2007); Appellate Body Report, Mexico - Tax Measures on Soft Drinks and Other Beverages, WT/DS308/AB/R (March 6, 2006); Panel Report, Mexico - Tax Measures on Soft Drinks and Other Beverages, WT/DS308/R, (October 7, 2005); Appellate Body Report, Dominican Republic-Measures Affecting the Importation and Internal Sale of Cigarettes, WT/DS302/AB/R (Apr. 25, 2005); Panel Report, Dominican Republic - Measures Affecting the Importation and Internal Sale of Cigarettes, WT/ DS302/R (Nov. 26, 2004); Appellate Body Report, United States - Sunset Reviews of Anti-Dumping Measures on Oil Country Tubular Goods from Argentina, WT/DS268/ AB/R (Nov. 29, 2004); Panel Report, United States - Sunset Reviews of Anti-Dumping Measures on Oil Country Tubular Goods from Argentina, WT/DS268/R (July 16, 2004); Appellate Body Report, United States - Continued Dumping and Subsidy Offset Act of 2000, WT/DS234/AB/R, WT/DS217/AB/R (Jan. 16, 2003) [hereinafter Appellate Body, US - Offset Act]; Panel Report, United States - Continued Dumping and Subsidy Offset Act of 2000, WT/DS234/R, WT/DS217/R (Sept. 16, 2002) [hereinafter US Offset Act]; Panel Report, Egypt - Definitive Anti-Dumping Measures on Steel Rebar from Turkey, WT/DS211/R (Aug. 8, 2002); Appellate Body Report, United States - Anti-Dumping Measures on Certain Hot-Rolled Steel Products from Japan, WT/ DS184/AB/R (July 24, 2001) [hereinafter US - Hot-Rolled Steel]; Panel Report, United States - Anti-Dumping Measures on Certain Hot-Rolled Steel Products from Japan, WT/DS184/R (Feb. 28, 2001) [hereinafter US - Hot-Rolled Steel]; Panel Report, United States - Anti-Dumping Measures on Stainless Steel Plate in Coils and Stainless Steel Sheet and Strip from Korea, WT/DS179/R (Dec. 22, 2000); Panel Report, Argentina - Measures Affecting the Export of Bovine Hides and the Import of Finished Leather, WT/DS155/R (Dec. 19, 2000) [hereinafter Argentina - Leather]; Panel Report, United States - Anti-Dumping Duty on Dynamic Random Access Memory Semiconductors (DRAMS) of One Megabit or Above from Korea, WT/DS99/R (Jan. 29, 1999); Appellate Body Report, Japan - Measures Affecting Agricultural Products, WT/DS76/AB/R (Feb. 22, 1999) [hereinafter Japan - Agricultural Products I; Panel Report, Japan - Measures Affecting Agricultural Products, WT/DS76/R (Oct. 27, 1998) [hereinafter Japan - Agricultural Products I; Appellate Body Report, US Shrimp, supra note 54; Panel Report, United States - Import Prohibition of Certain Shrimp and Shrimp Products, WT/DS58/R (May 15, 1998); Appellate Body Report, European Communities - Measures Affecting Importation of Certain Poultry Products, 
WT/DS69/AB/R (July 13, 1998); Panel Report, European Communities - Measures Affecting Importation of Certain Poultry Products, WT/DS69/R (Mar. 12, 1998); Panel Report, Indonesia - Certain Measures Affecting the Automobile Industry, WT/ DS64/R, WT/DS59/R, WT/DS55/R, WT/DS54/R (July 2, 1998); Panel Report, Japan - Measures Affecting Consumer Photographic Film and Paper, WT/DS44/R (Mar. 31, 1998) [hereinafter Japan - Film]; Appellate Body Report, European Communities Regime for the Importation, Sale and Distribution of Bananas, WT/DS27/AB/R (Sept. 9, 1997); Panel Report, European Communities - Regime for the Importation, Sale and Distribution of Bananas, WT/DS27/R (May 22, 1997); Appellate Body Report, US Underwear, supra note 52; Panel Report, United States - Restrictions on Imports of Cotton and Man-Made Fibre Underwear, WT/DS24/R (Nov. 8, 1996).

63. E.g., Panel Report, United States - Countervailing and Anti-Dumping Measures on Certain Products from China, WT/DS449/R (Mar. 27, 2014) [hereinafter US - CVD]; Panel Report, EU - Footwear, supra note 62; Appellate Body Report, EC - Iron or Steel Fasteners, supra note 62; Panel Report, EC - Iron or Steel Fasteners, supra note 62.

64. As one U.S. trade official recently told the author of this chapter: "our [US] problem is that we are transparent and this transparency opens our administrative procedures to increased scrutiny and more litigation." (Remarks by USTR Geneva, WCL course on WTO: Rule Making and Dispute Settlement, Summer 2013) (Notes are on file with Author). E.g., Panel Report, US - CVD, supra note 63; Panel Report, EU-Footwear, supra note 62.

65. Panel Report, $U S-C V D$, supra note 63.

66. U.S. Public Law 112-99 "An act to apply the countervailing duty provisions of the Tariff Act of 1930 to nonmarket economy countries, and for other purposes", $126 \mathrm{Sta}$. 265 (Mar. 13, 2012).

67. Panel Report, US - CVD, supra note 63, 17.59. According to Section 1(b), Section 701(f) applies to (1) all proceedings initiated under subtitle A of title VII of the U.S. Tariff Act of 1930 on or after November 20, 2006; (2) all resulting actions by U.S. Customs and Border Protection; and (3) all civil actions, criminal proceedings, and other proceedings before a U.S. federal court relating to proceedings referred to under (1) or actions referred to under (2). US Public Law 112-99 "An act to apply the countervailing duty provisions of the Tariff Act of 1930 to nonmarket economy countries, and for other purposes", 126 Sta. 265 (Mar. 13, 2012).

68. Ibid.

69. Ibid.

70. lbid.,977.216, 7.227.

71. Ibid, $177.228-7.232,7.244-7.245$.

72. As to China's Article X:1 claim, the panel found that because P.L. 112-99 was published on March 13, 2012-the same day that it was enacted-it was published promptly. Ibid.977.59, 7.60, 7.72-.73, 7.84 n.128. As to China's Article X:2 claim, the panel found that P.L. 112-99 neither effected an advance in a rate of duty on imports under an established and uniform practice, nor did it impose a new or more burdensome requirement on imports, because Commerce had an established practice of applying CVDs to NME imports-Commerce had made thirty-three CVD determinations in which duties were applied to NME imports. Ibid. $\$ \uparrow 7.169,7.173$. Moreover, the panel also cited to U.S. administrative law, recognizing that evidence of consistent application of a law includes an agency's interpretation and subsequent administration of that law, and that such an interpretation would govern. Ibid. $997.163-7.166$; 7.175-7.176. Lastly, as to China's Article X:3(b) claim, the panel found no inconsistency because (1) Article $X: 3$ (b) guarantees access to judicial review, as opposed to the outcome of judicial review, and because enactment of this type of legislation is infrequent. Ibid., $\uparrow\lceil 77.280,7.284$.

73. E.g., Request for Consultations by Argentina, United States - Measures Affecting the Importation of Fresh Lemons, WT/DS448/1 (Sept. 3, 2012) [hereinafter US - Lemons]; 
Request for Consultations by Vietnam, United States - Anti-Dumping Measures on Certain Frozen Warmwater Shrimp from Vietnam, WT/DS429/1 (Feb. 20, 2012) [hereinafter US - Frozen Warmivater Shrimp].

74. Request for Consultations by China, United States - Countervailing and Anti-Dumping Measures on Certain Products from China, WT/DS449/1 (Sept. 17, 2012).

75. Request for Consultations by Vietnam, US - Frozen Warmivater Shrimp, supra note 73, at 4-5.

76. World Trade Organization, United States - Anti-Dumping Measures on Certain Frozen Warmwater Shrimp from Viet Nam, http://www.wto.org/english/tratop_e/dispu_e/ cases_e/ds429_e.htm (last visited May 22, 2014).

77. Request for Consultations by Argentina, US - Lemons, supra note 73.

78. Ibid., at 2.

79. Ibid.

80. E.g., Panel Report, US - Customs Bond Directive, supra note 62; Panel Report, United States - Anti-Dumping and Countervailing Measures on Steel Plate from India, WT/ DS206/R (June 28, 2002); Panel Report, US - COOL, supra note 62; Panel Report, US - Anti-Dumping Measures on Oil Country Tubular Goods, WT/DS282/R (June 20, 2005); Request for Consultations by the European Communities, United States Sunset Reviews of Anti-Dumping and Countervailing Duties on Certain Steel Products from France and Germany, WT/DS262/1 (July 30, 2002); Panel Report, United States - Definitive Safeguard Measures on Imports of Certain Steel Products, WT/DS249/R, WT/DS251/R, WT/DS/252/R, WT/DS253/R, WT/DS254/R, WT/DS258/R, WT/ DS259/R (July 11, 2003); Panel Report, United States - Countervailing Duty Investigation on Dynamic Random Access Memory Semiconductors (DRAMS) from Korea, WT/DS296/R (Feb. 21, 2005); Panel Report, US - Offset Act, supra note 62; Panel Report, United States - Sunset Review of Anti-Dumping Duties on CorrosionResistant Carbon Steel Flat Products from Japan, WT/DS244/R (Aug. 14, 2003); Panel Report, US-Hot-Rolled Steel, supra note 62; Panel Report, US-Shrimp (Thailand), supra note 62.

81. See infra discussion in the section entitled "Three Attributes of Transparency in the WTO Context: Increased Centralization".

82. Panel Report, China-Raw Materials, supra note 62,77.636.

83. Ibid.

84. Ibid., $\uparrow 77.636,7.664$.

85. See supra discussion in the section entitled, "Transparency in WTO Dispute Settlement."

86. Appellate Body Report, US - Shrimp, supra note 54, $\{$ 1 156-57.

87. Ibid., 181-82.

88. Ibid., 182 .

89. Ibid. $\$ 183$.

90. For discussion of the use of Article $X$ as the primary basis for a WTO complaint, see the exposition of EC-Selected Customs Matters in the section entitled, "Three Attributes of Transparency in the WTO Context: Increased Uniformity".

91. Marrakesh Agreement, art. XVI.

92. TBT Agreement, art. 3.

93. Ibid., art. 3.1.

94. Ibid., art. 3.2.

95. Panel Report, China - Raw Materials, supra note 62, 凤 2.1, 2.3-.4.

96. Ibid.,97.178.

97. Ibid. $\$ 7.743-.745$.

98. Ibid.

99. Ibid., $\$ 7.737$.

100. Ibid., $\$ 7.685$.

101. Ibid.

102. Ibid., 田7.743-.746, 7.749-.752. 


\section{Research handbook on transparency}

103. See infra pp. 21-22.

104. Panel Report, China-Raw Materials, supra note 62.q7.744.

105. Ibid.,\$7.755.

106. Ibid.

107. Understanding on Rules and Procedures Governing the Settlement of Disputes art. 3.2, Apr. 15, 1994, Marrakesh Agreement Establishing the World Trade Organization, Annex 2, The Legal Texts: The Results of the Uruguay Round of Multilateral TRADE Negotiations 355 (2003), 1869 U.N.T.S. 401, 33 I.L.M. 1226 (1994).

108. According to the TBT Agreement, a technical barrier to trade is usually a regulation or a standard, "including packaging, marking and labeling requirements, and procedures for assessment of conformity with technical regulations and standards" that may constitute an "unnecessary obstacle] to international trade". See Preamble, art. 2.2. A technical regulation is a "[d]ocument which lays down product characteristics or their related processes and production methods, including the applicable administrative provisions, with which compliance is mandatory. It may also include or deal exclusively with terminology, symbols, packaging, marking or labeling requirements as they apply to a product, process or production method" Annex 1, \1. A standard is a "[d]ocument approved by a recognized body, that provides, for common and repeated use, rules, guidelines or characteristics for products or related processes and production methods, with which compliance is not mandatory. It may also include or deal exclusively with terminology, symbols, packaging, marking or labeling requirements as they apply to a product, process or production method". Annex 1, $\$ 2$.

109. TBT Agreement, art. 2.4.

110. Article 2.2 of the TBT Agreement provides examples of legitimate objectives: national security requirements; the prevention of deceptive practices; protection of human health or safety, animal or plant life or health, or the environment. In assessing these risks, the TBT Agreement also provides examples of relevant elements of consideration: available scientific and technical information, related processing technology, or intended end-uses of products, art. 2.2 .

111. Ibid., art. 2.5 .

112. A sanitary or phytosanitary measure is "[a]ny measure applied:

a. to protect animal or plant life or health within the territory of the Member from risks arising from the entry, establishment or spread of pests, diseases, diseasecarrying organisms or disease-causing organisms;

b. to protect human or animal life or health within the territory of the Member from risks arising from additives, contaminants, toxins or disease-causing organisms in foods, beverages or feedstuffs;

c. to protect human life or health within the territory of the Member from risks arising from diseases carried by animals, plants or products thereof, or from the entry, establishment or spread of pests; or

d. to prevent or limit other damage within the territory of the Member from the entry, establishment or spread of pests.

Sanitary or phytosanitary measures include all relevant laws, decrees, regulations, requirements and procedures including, inter alia, end product criteria; processes and production methods; testing, inspection, certification and approval procedures; quarantine treatments including relevant requirements associated with the transport of animals or plants, or with the materials necessary for their survival during transport; provisions on relevant statistical methods, sampling procedures and methods of risk assessment; and packaging and labelling requirements directly related to food safety." SPS Agreement Annex 1, $\$ 1$.

113. SPS Agreement, art. 3.1.

114. Ibid., art. 3.2.

115. Ibid., art. 3.4 .

116. Ibid. 
117. Panel Report, EC-Selected Customs Matters, supra note 14, $\$ 74.9-29$.

118. Appellate Body Report, EC-Selected Customs Matters, supra note 62,97197-200.

119. See DSU art. 1 (referring to the Dispute Settlement Body as the DSB).

120. Appellate Body Report, EC - Selected Customs Matters, supra note 62, 9166.

121. Appellate Body Report, European Communities - Regime for the Importation, Sale, and Distribution of Bananas, $\{200$, WT/DS27/AB/R (Sept. 9, 1997) (stating that the text and content of Article X:3(a), as well as a reading of the other paragraphs of Article $X$, make it clear that the requirements of Article $X$ apply not to "the laws, regulations, decisions and rulings themselves, but rather to the administration of those laws, regulations, decisions and rulings"); Appellate Body Report, European Communities - Measures Affecting Importation of Certain Poultry Products, \{115, WT/DS69/AB/R (July 13, 1998) (holding that Brazil's appeal falls outside of the scope of Article X to the extent that the appeal "relates to the substantive content of the EC rules themselves, and not to their publication or administration", as claims relating to the "WTOconsistency of such substantive content must be determined by reference to provisions of the covered agreements other than Article X ....").

122. Appellate Body Report, European Communities - Regime for the Importation, Sale, and Distribution of Bananas, supra note 121, \$200 ("Under Article X:3(a), a distinction must be made between the legal instrument being administered and the legal instrument that regulates the application or implementation of that instrument.")

123. Ibid., $\$ 303$.

124. Ibid.,ๆ298; see also Panel Report, Argentina - Leather, supra note 62,ף11.83 ("Customs laws should not vary .... . every exporter should be able to expect treatment of the same kind, in the same manner, both over time and in different places and with respect to other persons .... . Members [must] ensure that their laws are applied consistently and predictably ....").

125. Appellate Body Report, Thailand - Cigarettes, supra note 62, $\{202$.

126. Ibid.

127. Elsewhere, I have argued that through its transparency mandate, the WTO is more effective in combating corruption than direct anti-corruption initiatives such as those promoted by the World Bank. See generally World Bank, Governance and Development (1992), 3, FN2 http://documents.worldbank.org/curated/en/1992/04/440582/ governance-development (noting that governance has three distinct aspects, and the Bank has placed its focus on the latter two: "the processes by which authority is exercised in the management of a country's economic and social resources, and the capacity of governments to design, formulate, and implement policies, and, in general, to discharge government functions"). See generally Padideh Ala'i, The WTO and the Anti-Corruption Movement, 6 LoY. U. CHI. INT'L L. REv. 259 (2009). 


\section{APPENDIX A: ARTICLE X OF THE GATT 1994: PUBLICATION AND ADMINISTRATION OF TRADE REGULATIONS}

1. Laws, regulations, judicial decisions and administrative rulings of general application, made effective by any contracting party, pertaining to the classification or the valuation of products for customs purposes, or to rates of duty, taxes or other charges, or to requirements, restrictions or prohibitions on imports or exports or on the transfer of payments therefor, or affecting their sale, distribution, transportation, insurance, warehousing inspection, exhibition, processing, mixing or other use, shall be published promptly in such a manner as to enable governments and traders to become acquainted with them. Agreements affecting international trade policy which are in force between the government or a governmental agency of any contracting party and the government or governmental agency of any other contracting party shall also be published. The provisions of this paragraph shall not require any contracting party to disclose confidential information which would impede law enforcement or otherwise be contrary to the public interest or would prejudice the legitimate commercial interests of particular enterprises, public or private.

2. No measure of general application taken by any contracting party effecting an advance in a rate of duty or other charge on imports under an established and uniform practice, or imposing a new or more burdensome requirement, restriction or prohibition on imports, or on the transfer of payments therefor, shall be enforced before such measure has been officially published.

3. (a) Each contracting party shall administer in a uniform, impartial and reasonable manner all its laws, regulations, decisions and rulings of the kind described in paragraph 1 of this Article.

(b) Each contracting party shall maintain, or institute as soon as practicable, judicial, arbitral or administrative tribunals or procedures for the purpose, inter alia, of the prompt review and correction of administrative action relating to customs matters. Such tribunals or procedures shall be independent of the agencies entrusted with administrative enforcement and their decisions shall be implemented by, and shall govern the practice of, such agencies unless an appeal is lodged with a court or tribunal of superior jurisdiction within the time prescribed for appeals to be lodged by importers; Provided that the central administration of such agency may take steps to obtain a review of the matter 
in another proceeding if there is good cause to believe that the decision is inconsistent with established principles of law or the actual facts.

(c) The provisions of subparagraph (b) of this paragraph shall not require the elimination or substitution of procedures in force in the territory of a contracting party on the date of this Agreement which in fact provide for an objective and impartial review of administrative action even though such procedures are not fully or formally independent of the agencies entrusted with administrative enforcement. Any contracting party employing such procedures shall, upon request, furnish the CONTRACTING PARTIES with full information thereon in order that they may determine whether such procedures conform to the requirements of this subparagraph. 


\section{APPENDIX B: CHINA'S PROTOCOL OF ACCESSION, PART I - GENERAL PROVISIONS, ARTICLE 2(C): TRANSPARENCY}

1. China undertakes that only those laws, regulations and other measures pertaining to or affecting trade in goods, services, TRIPS or the control of foreign exchange that are published and readily available to other WTO Members, individuals and enterprises, shall be enforced. In addition, China shall make available to WTO Members, upon request, all laws, regulations and other measures pertaining to or affecting trade in goods, services, TRIPS or the control of foreign exchange before such measures are implemented or enforced. In emergency situations, laws, regulations and other measures shall be made available at the latest when they are implemented or enforced.

2. China shall establish or designate an official journal dedicated to the publication of all laws, regulations and other measures pertaining to or affecting trade in goods, services, TRIPS or the control of foreign exchange and, after publication of its laws, regulations or other measures in such journal, shall provide a reasonable period for comment to the appropriate authorities before such measures are implemented, except for those laws, regulations and other measures involving national security, specific measures setting foreign exchange rates or monetary policy and other measures the publication of which would impede law enforcement. China shall publish this journal on a regular basis and make copies of all issues of this journal readily available to individuals and enterprises.

3. China shall establish or designate an enquiry point where, upon request of any individual, enterprise or WTO Member all information relating to the measures required to be published under paragraph $2(C) 1$ of this Protocol may be obtained. Replies to requests for information shall generally be provided within 30 days after receipt of a request. In exceptional cases, replies may be provided within 45 days after receipt of a request. Notice of the delay and the reasons therefor shall be provided in writing to the interested party. Replies to WTO Members shall be complete and shall represent the authoritative view of the Chinese government. Accurate and reliable information shall be provided to individuals and enterprises. 


\section{APPENDIX C: ARTICLE XX OF THE GATT 1994: GENERAL EXCEPTIONS}

Subject to the requirement that such measures are not applied in a manner which would constitute a means of arbitrary or unjustifiable discrimination between countries where the same conditions prevail, or a disguised restriction on international trade, nothing in this Agreement shall be construed to prevent the adoption or enforcement by any contracting party of measures:

(a) necessary to protect public morals;

(b) necessary to protect human, animal or plant life or health;

(c) relating to the importations or exportations of gold or silver;

(d) necessary to secure compliance with laws or regulations which are not inconsistent with the provisions of this Agreement, including those relating to customs enforcement, the enforcement of monopolies operated under paragraph 4 of Article II and Article XVII, the protection of patents, trade marks and copyrights, and the prevention of deceptive practices;

(e) relating to the products of prison labour;

(f) imposed for the protection of national treasures of artistic, historic or archaeological value;

(g) relating to the conservation of exhaustible natural resources if such measures are made effective in conjunction with restrictions on domestic production or consumption;

(h) undertaken in pursuance of obligations under any intergovernmental commodity agreement which conforms to criteria submitted to the CONTRACTING PARTIES and not disapproved by them or which is itself so submitted and not so disapproved;

(i) involving restrictions on exports of domestic materials necessary to ensure essential quantities of such materials to a domestic processing industry during periods when the domestic price of such materials is held below the world price as part of a governmental stabilization plan; Provided that such restrictions shall not operate to increase the exports of or the protection afforded to such domestic industry, and shall not depart from the provisions of this Agreement relating to non-discrimination;

(j) essential to the acquisition or distribution of products in general or local short supply; Provided that any such measures shall be consistent with the principle that all contracting parties are entitled to an equitable share of the international supply of such products, and that any such measures, which are inconsistent with the other provi- 


\section{Research handbook on transparency}

sions of the Agreement shall be discontinued as soon as the conditions giving rise to them have ceased to exist. The CONTRACTING PARTIES shall review the need for this sub-paragraph not later than 30 June 1960. 
Transparency in international economic relations and the WTO 399

\section{GLOSSARY}

APA Administrative Procedures Act

CVDs Countervailing Duties

DSB Dispute Settlement Body

GATS General Agreement on Tariffs and Trade of 1947

GATT 1947 General Agreement on Tariffs and Trade of 1947

GATT 1994 General Agreement on Tariffs and Trade of 1994

Measures "Laws, regulations, judicial decisions and administrative rulings of general application"

MOFCOM China's Ministry of Commerce

NTBs Non-Trade Barriers

TPRM Trade Policy Review Mechanism

TRIPS Trade-Related Aspects of Intellectual Property Rights

WTO World Trade Organization 